\title{
Feedback Regulation of Cathepsin $C$ by the Propeptide Dipeptides of Granzymes A and B
}

\author{
Janja Božič ${ }^{1}$ and Iztok Dolenc ${ }^{1, *}$ \\ ${ }^{1}$ Department of Biochemistry and Molecular and Structural Biology, Jozef Stefan Institute, Jamova 39, \\ SI-1000 Ljubljana, Slovenia \\ *Corresponding author: E-mail: iztok.dolenc@ijs.si \\ Tel.: +38614773776 Fax: +38614773984
}

Received: 04-11-2019

\begin{abstract}
Granzymes A and B are activated by proteolytic removal of their N-terminal dipeptides by cathepsin C (dipeptidyl-peptidase I). However, the possible physiological role of the cleaved dipeptides Glu-Lys and Gly-Glu is not yet understood. In this study, adding either of the two dipeptides to NK-92 cells, resulted in enhanced cytotoxicity toward the targeted $\mathrm{K} 562$ cells and increased death rate of the target cells. Cathepsin $\mathrm{C}$ is known to generate cytotoxic polymers from various dipeptides, however, in the case of the dipeptides Glu-Lys and Gly-Glu, cathepsin C was unable to polymerize them. Unexpectedly the dipeptides were found to be inhibitors of the transferase activity of cathepsin C (IC50<20 mM), and weak competitive inhibitors of the peptidase activity with $\mathrm{K}_{\mathrm{i}}$ values in the millimolar range. This suggests that the dipeptides can play role in a feedback loop that controls transferase and proteolytic activities of cathepsin $\mathrm{C}$ in various biological processes.
\end{abstract}

Keywords: Cathepsin C; granzyme; HPLC; dipeptides; transferase activity; product inhibition

\section{Introduction}

Natural killer cells (NK cells) are a subpopulation of lymphocytes, and as a part of the innate immune response mediate cytotoxic activity against cancer cells and virally infected cells. ${ }^{1} \mathrm{~A}$ finely controlled mechanism is necessary to eliminate harmful cells from spreading in the body. Recognition of the infected and MHC class I-deficient cells triggers different cascades of the cytotoxic process. ${ }^{2}$ One of the most important processes is the granzyme's route, including the movement of granules toward the immunological synapse. ${ }^{2}$ Granzymes A and B are the most abundant granzymes and thought to play a leading role in granzyme-mediated cytotoxicity. ${ }^{3}$ They are synthesized in the form of inactive zymogens, and during the activation of NK cells, cysteine cathepsin C (dipeptidyl-peptidase I) activates granzymes by removing the $\mathrm{N}$-terminal dipeptide. ${ }^{4}$ Following the removal of dipeptide, conformational rearrangements of the newly formed $\mathrm{N}$-terminal occur. ${ }^{5}$ The conserved $\mathrm{N}$-terminal tail of the mature enzyme is further inserted in the interior of the protein, forming an active granzyme. ${ }^{6}$ Afterward, these granzymes are vectorially released into the submicroscopic intercellular cleft between the NK cell and the target cell. ${ }^{2}$ From this immu- nological synapse, granzymes, with the support of perforin, translocate into the cytoplasm of the target cells, where they cleave and activate multiple critical protein substrates, resulting in the death of the target cell. ${ }^{7}$

The activating protease, cathepsin $\mathrm{C}^{4}$ is a cysteine protease and member of the papain family, ${ }^{8}$ inhibited by cystatins. ${ }^{9}$ The enzyme is ubiquitously expressed in various tissues, ${ }^{10,11}$ having several important functions. ${ }^{12-14}$ The inherited mutation in the cathepsin $\mathrm{C}$ gene, generating an inactive enzyme, causes autosomal-recessive disease Papillon-Lefévre syndrome. ${ }^{15}$ Opposite, deficiency of cathepsin $C$ lighten severity of acute pancreatitis by reduction of neutrophil elastase activation and cleavage of E-cadherin. ${ }^{16}$ Cathepsin $C$ is synthesized as a single chain preproenzyme. ${ }^{17}$ During activation, the tetrameric form of the mature enzyme is assembled. ${ }^{18}$ From the crystal structure of the mature enzyme it is evident that the monomer consists of N-terminal fragment of 119 residues from Asp1 to Gly119, termed "exclusion domain", and 233 residues of the papain-like structure. ${ }^{18}$ However, the enzyme is functionally active only as tetramer composed of four identical subunits, ${ }^{19,20}$ with four active site clefts positioned at the tetrahedral corners of the molecule. ${ }^{18}$ At the end of each active site cleft is positioned the $\mathrm{N}$-terminus of the exclusi- 
on domain, which determines dipeptidyl peptidase activity. ${ }^{18}$ The carboxylic group of Asp1 side chain controls the entry into the $\mathrm{S} 2$ binding pocket by recognizing the $\mathrm{N}$-terminal amino group of the substrate. ${ }^{18}$ At the bottom of the pocket are chloride ions which provide additional negative charges and are required for cathepsin C activity. ${ }^{18}$ The enzyme is optimally proteolytically active at slightly acidic $\mathrm{pH}^{17}$ and is relatively unspecific. It cleaves dipeptides from proteins and peptidyl substrates until the $\mathrm{N}$-terminus is no more available or a stop sequence of proline is reached. ${ }^{21}$ Relatively unspecific cleavage patterns exclude cleavages of substrates with positively charged amino acids (Arg and Lys) on the N-terminal part of proteins (P2 position). ${ }^{22}$ At neutral $\mathrm{pH}$ and above, the enzyme exhibits dipeptidyl transferase activity. ${ }^{23}$ Its perhaps the best known example is the lysosomotropic detergent LeuLeuOMe, which accumulates in the lysosomes. ${ }^{24}$ Once polymerized, it triggers the lysosomal pathway of cell death. ${ }^{25,26}$

In this study, we found that the dipeptides Glu-Lys and Gly-Glu, released during activation of granzymes A and $\mathrm{B}$, promote cell death of target cells when incubated together with NK cells, but cannot be polymerized by cathepsin C. Instead, they act as weak competitive inhibitors of the enzyme, blocking both the proteolytic and transferase activities of the enzyme.

\section{Experimental}

\section{1. Materials}

Acetonitrile (ACN) and pentafluoropropionic acid (PFPA) were supplied by Sigma (Germany). Ultrapure water was obtained from a Milli-Q system (Millipore, Bedford, MA, USA). Dipeptides Glu-Lys and Gly-Glu, their amides, and the fluorogenic substrate Gly-Phe-AMC were obtained from Bachem (Switzerland). The human NK cell line was derived from blood, mononuclear cells, NK-92, and human hematopoietic malignant cell line K562, were kindly provided by E. Vivier (Marseille, France). The growth medium was RPMI-1640 (Sigma-Aldrich).

\section{2. Cytotoxicity Assay}

A fluorescence-activated cell sorter (FACS) was used to perform the NK cell cytotoxicity assay, as described previously. ${ }^{27}$ The following day, the target K562 cell ( $10^{5}$ cells) were added at the desired ratio, 10:1, and the mixture was incubated for $4 \mathrm{~h}$ at $37^{\circ} \mathrm{C}$ and $5 \% \mathrm{CO}_{2} .0 .5 \mu \mathrm{M}$ propidium iodide (Sigma-Aldrich) was used to evaluate cell viability. The analysis was performed using a FACSCalibur flow cytometer (Becton-Dickinson, USA), and the data acquisition was performed using Cellquest software. The cells were incubated overnight with a supplement of $1 \mathrm{mM}$ dipeptides Glu-Lys or Gly-Glu. The obtained results are presented as mean values with standard deviations of at least three replicates.

\subsection{Cathepsin C expression, Activation, and Purification}

Human recombinant procathepsin $\mathrm{C}$ was expressed, activated and purified, essentially as described earlier with some minor modifications. ${ }^{28}$ Briefly, activation by cathepsin $\mathrm{L}$ was performed overnight at $4{ }^{\circ} \mathrm{C}$ in an activating buffer $(250 \mathrm{mM}$ sodium acetate $\mathrm{pH} 5.5,150 \mathrm{mM}$ $\mathrm{NaCl}, 10 \mathrm{mM}$ DTT). Afterward, the protein mixture was loaded into a Sepharose 12 size-exclusion column, using fast protein liquid chromatography (AKTA system, GE Healthcare, Sweden), equilibrated with $50 \mathrm{mM}$ of sodium acetate, $1 \mathrm{mM}$ EDTA, and $300 \mathrm{mM}$ of $\mathrm{NaCl}$, at a pH level of 5.5 , and a flow rate of $0.5 \mathrm{ml} / \mathrm{min}$. The protein peak at 200 $\mathrm{kDa}$ was collected, concentrated to concentration $1 \mathrm{mg} /$ $\mathrm{ml}$, and analyzed using SDS-PAGE.

\section{4. High-performance Liquid Chromatography (HPLC) Analysis of Dipeptide Polymerization}

The dipeptides were dissolved in double distilled water to $1 \mathrm{M}$ concentration and further used in the reaction with a final concentration of $40 \mathrm{mM}$. The final concentration of cathepsin C was $75 \mathrm{nM}$ (an active concentration, determined as earlier described ${ }^{18}$ ) and the buffer in the reaction was PBS $\left(10 \mathrm{mM} \mathrm{NaH}_{2} \mathrm{PO}_{4}, 1.8 \mathrm{mM} \mathrm{KH}_{2} \mathrm{PO}_{4}\right.$, $137 \mathrm{mM} \mathrm{NaCl}, 2.7 \mathrm{mM} \mathrm{KCl}, \mathrm{pH}$ 7.4), with $5 \mathrm{mM}$ DTT. Next, polymerization reaction was performed in $100 \mu \mathrm{l}$ volume for four hours at $37^{\circ} \mathrm{C}$, and then an aliquot of $20 \mu \mathrm{l}$ was applied on an Ascentis Express Peptide ES-C18 reversed phase column $(150 \mathrm{~mm} \times 2.1 \mathrm{~mm}, 2.7 \mu \mathrm{m})$ (Sigma, Germany). The analysis was completed on an HPLC system (Waters, Milford, MA, USA) using the Waters M600 solvent delivery module and the Waters M2489 detector system. The analysis of the reaction mixture was optimized for the separation of dipeptides, using $0.1 \%$ PFPA as anionic ion-pairing reagents for reversed-phase high-performance liquid chromatography (RP-HPLC). ${ }^{29} \mathrm{~A}$ gradient elution from water/0.1\% PFPA (phase A) to acetonitrile/water $60 \% / 40 \%(\mathrm{v} / \mathrm{v})$ with $0.1 \%$ PFPA (phase B) was used to separate the products.

\section{5. Determination of Inhibition Constants for Glu-Lys and Gly-Glu}

The active site titration of cathepsin $\mathrm{C}$, the determination of the inhibition type, and the inhibition constant $\left(\mathrm{K}_{\mathrm{i}}\right)$ for the interaction of dipeptides with cathepsin $\mathrm{C}$ were carried out as described earlier. ${ }^{18}$ Briefly, measurements were performed in $50 \mathrm{mM}$ sodium acetate, $1 \mathrm{mM}$ EDTA, and $300 \mathrm{mM} \mathrm{NaCl}, \mathrm{pH}$ 5.5. Five hundred $\mu \mathrm{l}$ of the reaction mixture contained $0.02 \mathrm{nM}$ cathepsin $\mathrm{C}$ and increased concentration of the dipeptides Glu-Lys or GlyGlu. In addition, these experiments were performed at different concentrations of the substrate Gly-Phe-AMC to 
identify the inhibition type. The release of the product at $25^{\circ} \mathrm{C}$ was monitored with a Perkin-Elmer spectrofluorimeter.

\section{6. Molecular Docking}

UCSF Chimera $1.13 \mathrm{rc}^{30}$ has been used to prepare the structure of cathepsin C (PDB: 1K3B) for docking. Docking simulations of ligands were performed using the $\mathrm{Au}$ todock Vina Plugin ${ }^{31}$ and the results were examined with UCSF Chimera. Dipeptides were docked with the enzyme's structure giving a Vina score, which is the predicted affinity of the molecule to bind to the PDB structure, calculated in $\mathrm{kcal} \mathrm{mol}^{-1}$.

\section{7. Molecular Modeling of Progranzyme B}

The three-dimensional model of human granzyme $B$ was generated with the online server program I-TASSER, ${ }^{32}$ using the progranzyme $\mathrm{K}$ crystal structure (PDB entry $1 \mathrm{MZA})^{5}$ as the primary template. Structures were visualized with UCSF Chimera 1.13 rc. $^{30}$

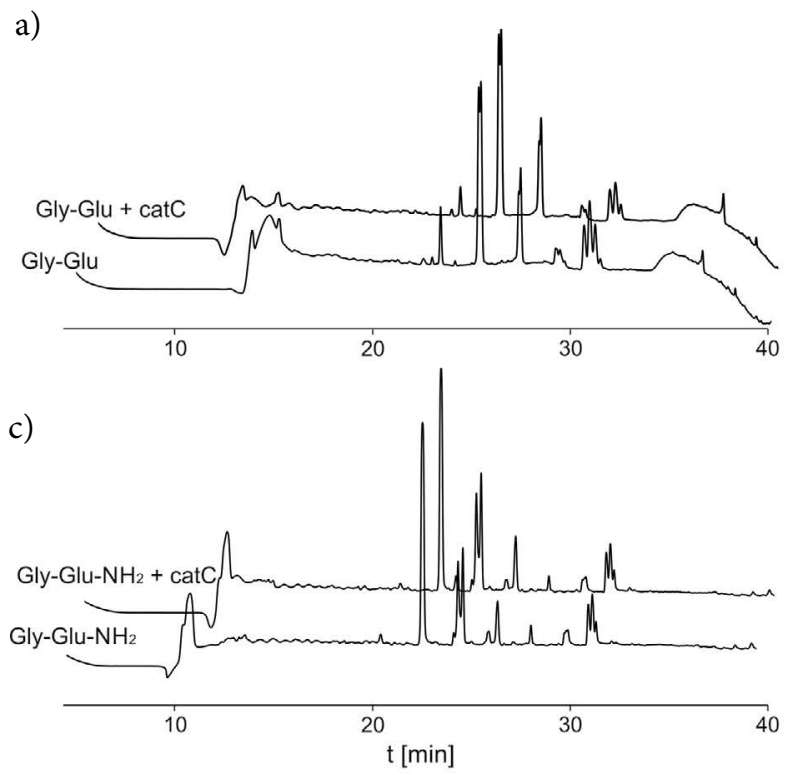

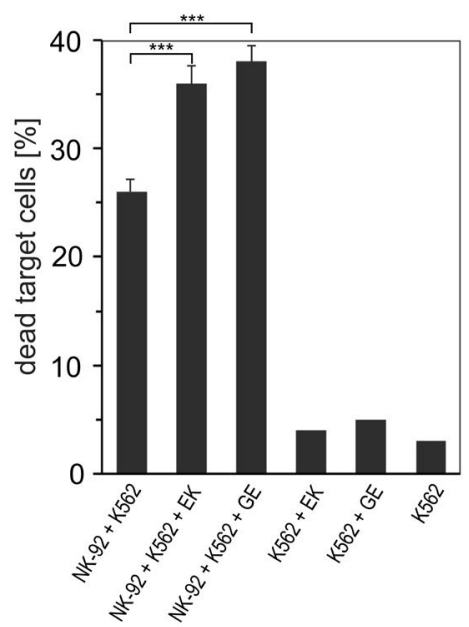

Figure 1. Dipeptides Glu-Lys (EK) or Gly-Glu (GE) enhanced the cytotoxic effect of NK-92 cells toward K562 target cells. NK-92 cells were incubated overnight with $1 \mathrm{mM}$ dipeptide supplement, and a number of dead target cells was compared to the control samples. The impact of the dipeptides on the target cells is seen as their enhanced death. The data are expressed as mean \pm standard deviations $(\mathrm{SD})$ of at least three independent experiments performed in duplicate. A t-test is used to compare the mean of two given samples. P value $(* *)$ is below 0.001 .
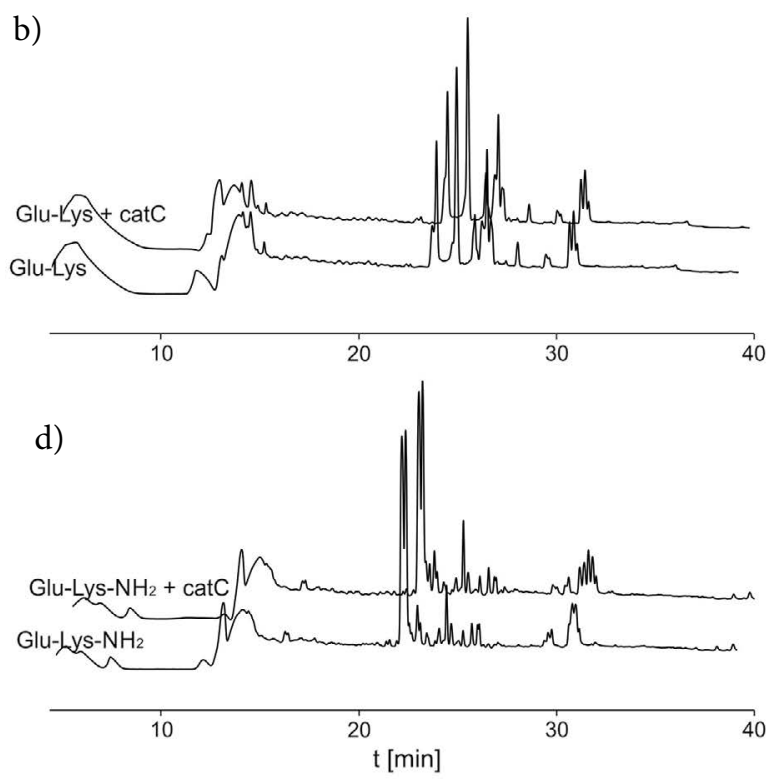

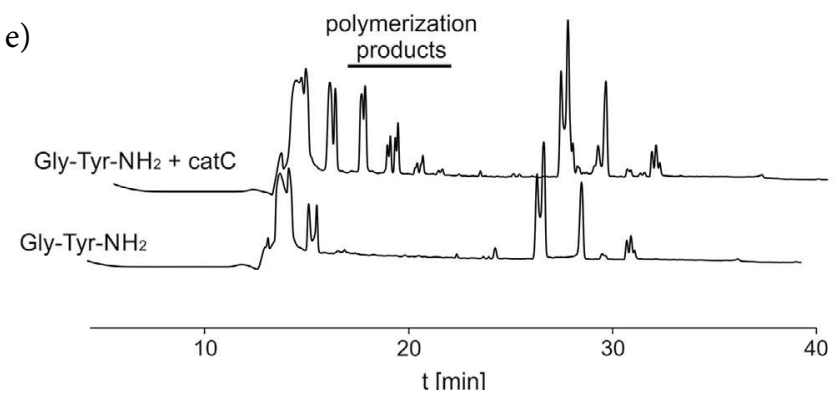

Figure 2. Dipeptides Gly-Glu, Glu-Lys or their amide forms are not polymerized by cathepsin C. Reverse phase HPLC using $0.1 \%$ pentafluoropropionic acid (PFPA) as anionic ion-pairing reagents for separation, following a four-hour reaction with cathepsin C, in comparison to the control samples (a) Gly-Glu, (b) Glu-Lys, (c) Gly-Glu- $\mathrm{NH}_{2}$, (d) Glu-Lys- $\mathrm{NH}_{2}$. (e) Polymerization of Gly-Tyr- $\mathrm{NH}_{2}$ by cathepsin C as a control. For clarity purposes, the upper chromatograms are slightly shifted. 


\section{Results}

\section{1. Dipeptides Glu-Lys and Gly-Glu Enhance the Cytotoxicity of NK-92 Cells}

In order to test, whether the released granzyme propeptides Glu-Lys and Gly-Glu, have an additional role in NK cell-mediated cytotoxicity, we incubated the dipeptides overnight with the target K562 cells, prior to addition of NK-92 cells. The reaction resulted in a substantially enhanced cytotoxicity, which was almost 1.5 -fold in case of Gly-Glu dipeptide (Figure 1).

\section{2. Cathepsin $\mathrm{C}$ is unable to Polymerize Dipeptides Gly-Glu and Glu-Lys, Nor their Amide Forms}

As the increased cytotoxicity could have resulted from cathepsin C-mediated polymerization of the dipeptides, we next tested whether the enzyme was able to polymerize both dipeptides. Therefore, we incubated the reaction mixture containing the dipeptides Gly-Glu or Glu-Lys, for four hours with cathepsin C. However, no larger peptides were found after separation of the mixture on a reverse phase C18 column of the HPLC system (Figure 2A and Figure $2 \mathrm{~B}$ ). As cathepsin $\mathrm{C}$ is known to prefer dipeptide-amides, we next used the amide forms of the two dipeptides, Gly-Glu-NH $\mathrm{NH}_{2}$ and Glu-Lys- $\mathrm{NH}_{2}$. To our surprise, the amide dipeptides were not polymerized, similar to the free dipeptides (Figure 2C and Figure 2D). In contrast, cathepsin $\mathrm{C}$ polymerized the dipeptide-amide Gly-Tyr$-\mathrm{NH}_{2}$, which was already reported to be a transferase substrate of cathepsin $\mathrm{C}^{33}$ (Figure 3).

\section{3. Dipeptides Glu-Lys and Gly-Glu are Inhibitors of Cathepsin C}

Finally, we investigated, whether the two dipeptides, Glu-Lys and Gly-Glu, have any effect on cathepsin C activi-

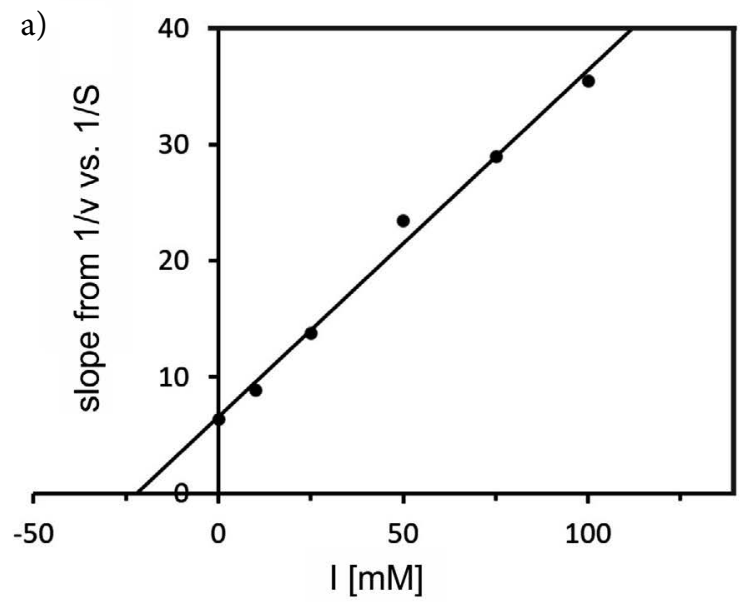

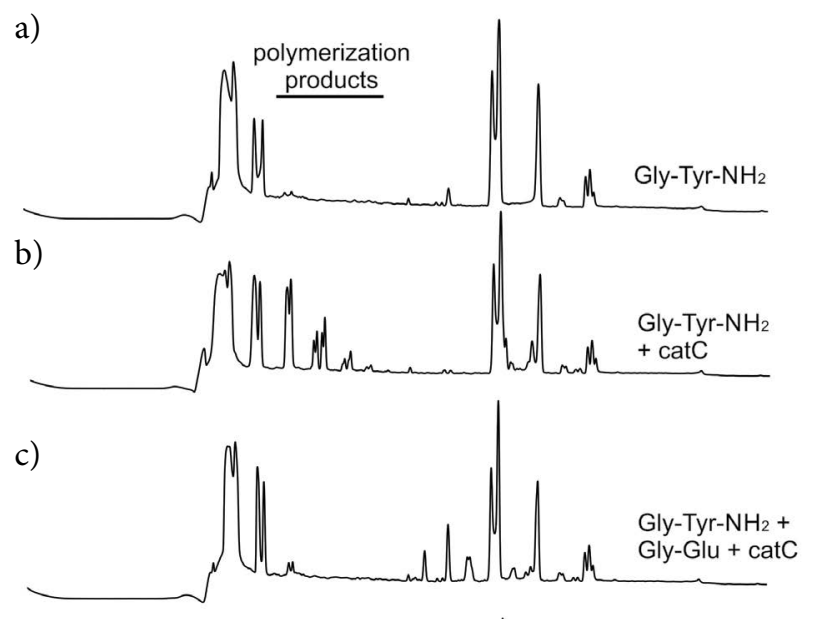

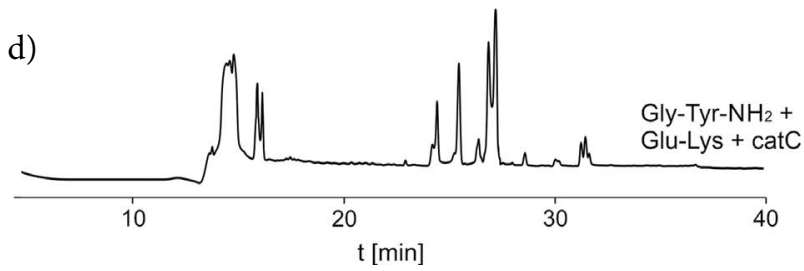

Figure 3. Gly-Glu, the prodipeptide from granzyme B, inhibits the transferase and the peptidase activity of cathepsin C. (a) The dipeptide Gly-Tyr- $-\mathrm{NH}_{2}$ as a control sample. (b) Polymerization of GlyTyr- $\mathrm{NH}_{2}$ by cathepsin $\mathrm{C}$ (catC) using a reverse phase HPLC. The products of polymerization are eluted with a retention time 15-20 minutes. Dipeptides Gly-Glu (b) and Glu-Lys (c) inhibit polymerization reaction of Gly-Tyr- $\mathrm{NH}_{2}$ by catC.

ties. Both dipeptides were found to inhibit the transferase activity of cathepsin $\mathrm{C}$, monitored by the polymerization of the Gly-Tyr- $\mathrm{NH}_{2}$ substrate. The separation of products on a reverse phase C18 column of HPLC system, obtained from the polymerization reaction of Gly-Tyr- $\mathrm{NH}_{2}$ with cathepsin $\mathrm{C}$ is illustrated (Figure 3). The formation of the polymerization product was completely inhibited by both dipeptides at $40 \mathrm{mM}$ concentration, indicating an inhibition of the cathepsin $\mathrm{C}$ transferase activity at neutral $\mathrm{pH}$ (pH 7.4; Fi-

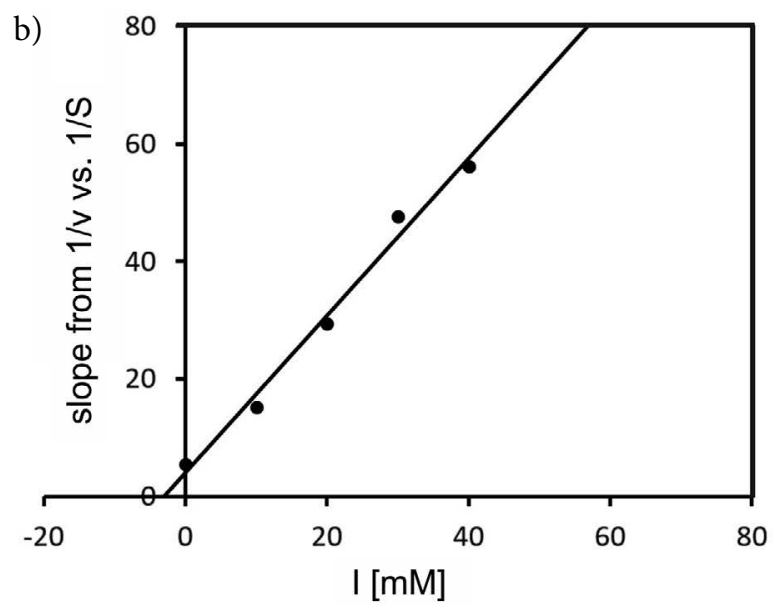

Figure 4. Proteolytic inhibition of cathepsin C by dipeptides Glu-Lys and Gly-Glu. $\mathrm{K}_{\mathrm{i}}$ values for inhibition of cathepsin C by dipeptides (a) Glu-Lys $(20 \mathrm{mM})$ and (b) Gly-Glu $(2.5 \mathrm{mM})$ were determined by secondary plots. 
gure 3). Moreover, both dipeptides inhibited also the peptidase activity of cathepsin $\mathrm{C}$ as monitored by the hydrolysis of fluorogenic substrate Gly-Phe-AMC at the more acidic pH 5.5 (Figure 4). The dipeptides Glu-Lys and Gly-Glu inhibited cathepsin $C$ with $K_{i}$ values of $20 \mathrm{mM}$ and $2.5 \mathrm{mM}$, respectively. The results revealed that both dipeptides are weak competitive inhibitors of cathepsin C.

\section{4. Molecular Docking of Dipeptides}

In order to understand the potential mechanism of dipeptide binding at the structural level, we modelled the dipeptides into the active site of human cathepsin C. The crystal structure of human cathepsin C (PDB: $1 \mathrm{KBB})^{18}$ was used to assess the fitness and orientation of the docked dipeptides. As Glu-Lys and Gly-Glu shown to be competitive inhibitors of cathepsin $\mathrm{C}$, suggesting a binding into the active site of the enzyme, we limited our docking in the area of a substrate binding. Despite the similarities in docking sites, some differences were apparent (Figure 5). All representative docking predictions with a high score of probability fitted into the S1 position of the active cleft.
The best fit was calculated for the Gly-Tyr- $\mathrm{NH}_{2}$ dipeptide, the substrate which was successfully polymerized (Figure $5 \mathrm{~A}$ ), and can be compared with the position of the inhibitor Ser-Tyr-CN (Figure 5B). Docking of Gly-Tyr- $\mathrm{NH}_{2}$ into the $3 \mathrm{D}$ structure of cathepsin $\mathrm{C}$ placed the dipeptide in the position stabilized by the amino acid residues Gly232 and Glu275 of the S1 binding site, and Asp1 at the entrance of the S2 pocket. The amide group was facing towards the S1' site, interacting with Asn380.

Docking studies for dipeptides Glu-Lys and Gly-Glu suggested representative positions with similar scores. Their top-ranked positions were placed in the active site cleft of cathepsin C, where both dipeptides were well stabilized. The dipeptide Glu-Lys interacts with Trp405, Asn380, Thr379, and Asp1, expanding the side chain towards S2 (Figure 5C). Opposite, Gly-Glu stretches between S1 and S1', and is stabilized with Val352, Asn380, Trp405, Gln228, Gly232, and Cys234 (Figure 5D). However, the predicted positions do not favor catalysis by the enzyme. Namely, the docking studies predicted their binding to the S1 and S1' positions, with peptide bond in a position that cannot be cleaved. a) substrate Gly-Tyr- $\mathrm{NH}_{2}$

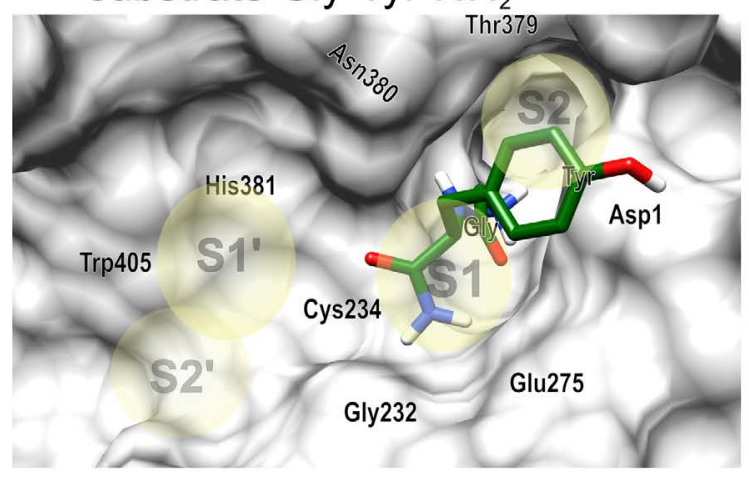

c) reversible inhibitor Glu-Lys

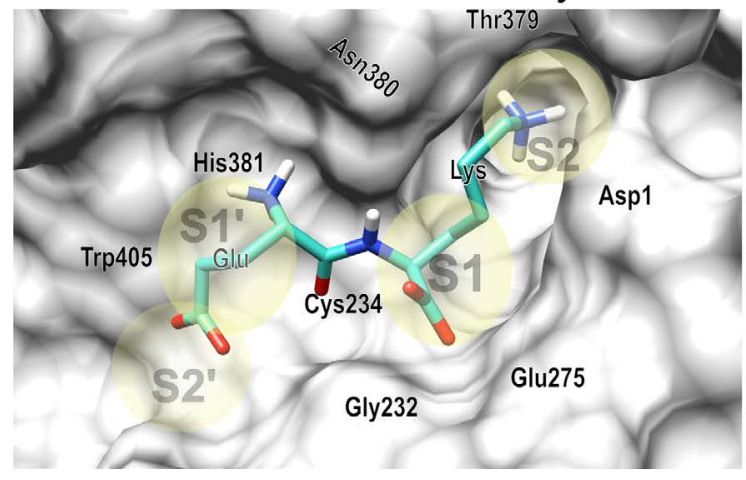

b) irreversible inhibitor Ser-Tyr-CN

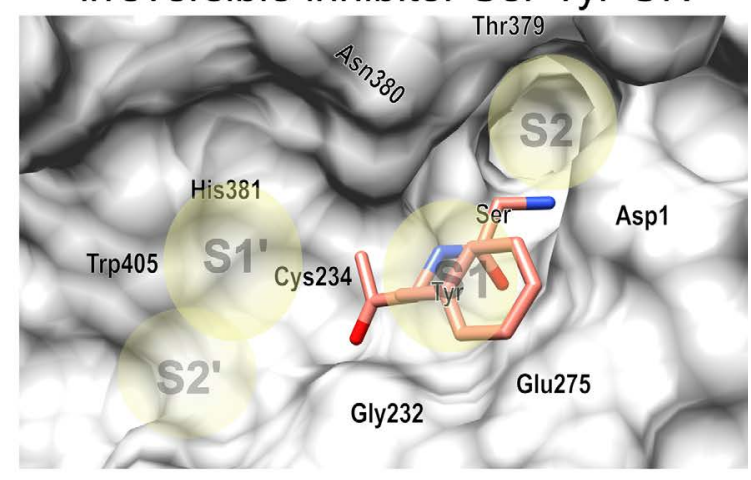

d) reversible inhibitor Gly-Glu

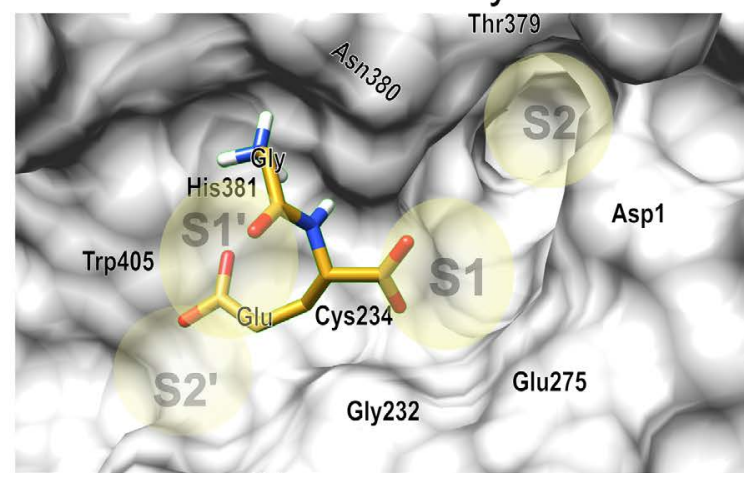

Figure 5. The active site of cathepsin $\mathrm{C}$ with selected predicted positions of dipeptides using docking predictions in comparison to the experimentally determined position of the inhibitor Ser-Tyr-CN in the crystal structure of cathepsin C. ${ }^{22}$ Docking simulations of ligands were performed using the Autodock Vina Plugin ${ }^{31}$ and the results were visualized with UCSF Chimera $1.13 \mathrm{rc}^{30}$ (a) The predicted accommodation of dipeptide-amide Gly-Tyr- $\mathrm{NH}_{2}$, a substrate for polymerization by cathepsin C; (b) the covalently bound irreversible inhibitor Ser-Tyr-CN in the crystal structure of cathepsin C. (c) The best predicted binding of the inhibitory dipeptide Glu-Lys, the prodipeptide of granzyme A. (d) The best predicted position of the inhibitory dipeptide Gly-Glu, the prodipeptide of granzyme B. 


\section{5. Comparison of the Putative Structure of Progranzyme B with Granzyme B}

To further investigate the inhibitory role of N-terminal dipeptides from granzymes, we performed sequence alignment of the $\mathrm{N}$-terminal parts of granzymes $\mathrm{A}$ and $\mathrm{B}$ in comparison to selected serine proteases with dipeptide proregions (Figure 6A). This similarity enabled the modeling of the structure of progranzyme B, using the crystal structure of progranzyme $\mathrm{K}$ as a template. The obtained result, with the $\mathrm{C}$-score value of 1.52, signifies an accurate model with high confidence. Comparing both $3 \mathrm{D}$ structures, the model structure of progranzyme $B$, and the crystal structure of granzyme $B$, revealed exposure of the N-terminal prodipeptide (Figure $6 \mathrm{~B}$ ), which is removed by cathepsin $\mathrm{C}$. The $\mathrm{N}$-terminus of the mature granzyme $\mathrm{B}$ is buried inside the protein (Figure 6C).

\section{Discussion}

Activation of neutrophil serine proteases, granzymes, and cathepsin $\mathrm{G}$ is achieved by a rapid truncation of the N-terminal dipeptide by cathepsin C. ${ }^{4}$ Possible involvement of these dipeptides in the cellular protection system is supported by the immunomodulatory effect of dipeptidyl derivatives, described earlier. ${ }^{34}$ Therefore, the cytotoxic activity of the NK-92 cells towards the target K562 cells was evaluated in the presence of prodipeptides from granzyme A (Glu-Lys) or granzyme B (Gly-Glu). The presence of either dipeptide enhanced the cytotoxic response and cell death of the target cells (Figure 1). One possible explanation for this increased cytotoxicity would be polymerization of the released dipeptides by cathepsin $\mathrm{C}$ into membranolytic forms, as seen for Leu-Leu-OMe, ${ }^{24}$ acting as substance with cytotoxic activity. ${ }^{35}$ However, cathepsin $\mathrm{C}$ failed to polymerize any of the two N-terminal dipeptides of granzymes $\mathrm{A}$ and $\mathrm{B}$ (Figure 2).

Moreover, cathepsin $\mathrm{C}$ even failed to polymerize the amide forms of the two dipeptides, i.e. Glu-Lys- $\mathrm{NH}_{2}$ and Gly-Glu- $\mathrm{NH}_{2}$, although the enzyme preferentially polymerizes dipeptidyl esters or amides, ${ }^{21,33}$ such as also seen for Gly-Tyr- $\mathrm{NH}_{2}$ we used for the positive control. ${ }^{33}$ Furthermore, the two granzymes-originating dipeptides Glu-Lys and Gly-Glu inhibited transferase and peptidase activities of cathepsin $\mathrm{C}$ in the millimolar range. Similarly, it has been shown that some dipeptides inhibit dipeptidyl peptidase IV in $\mathrm{mM}$ range and have potential influence on of the enzyme's function in diabetes. ${ }^{36,37}$ Our observation is in agreement with previous findings, where some dipepti-

a)
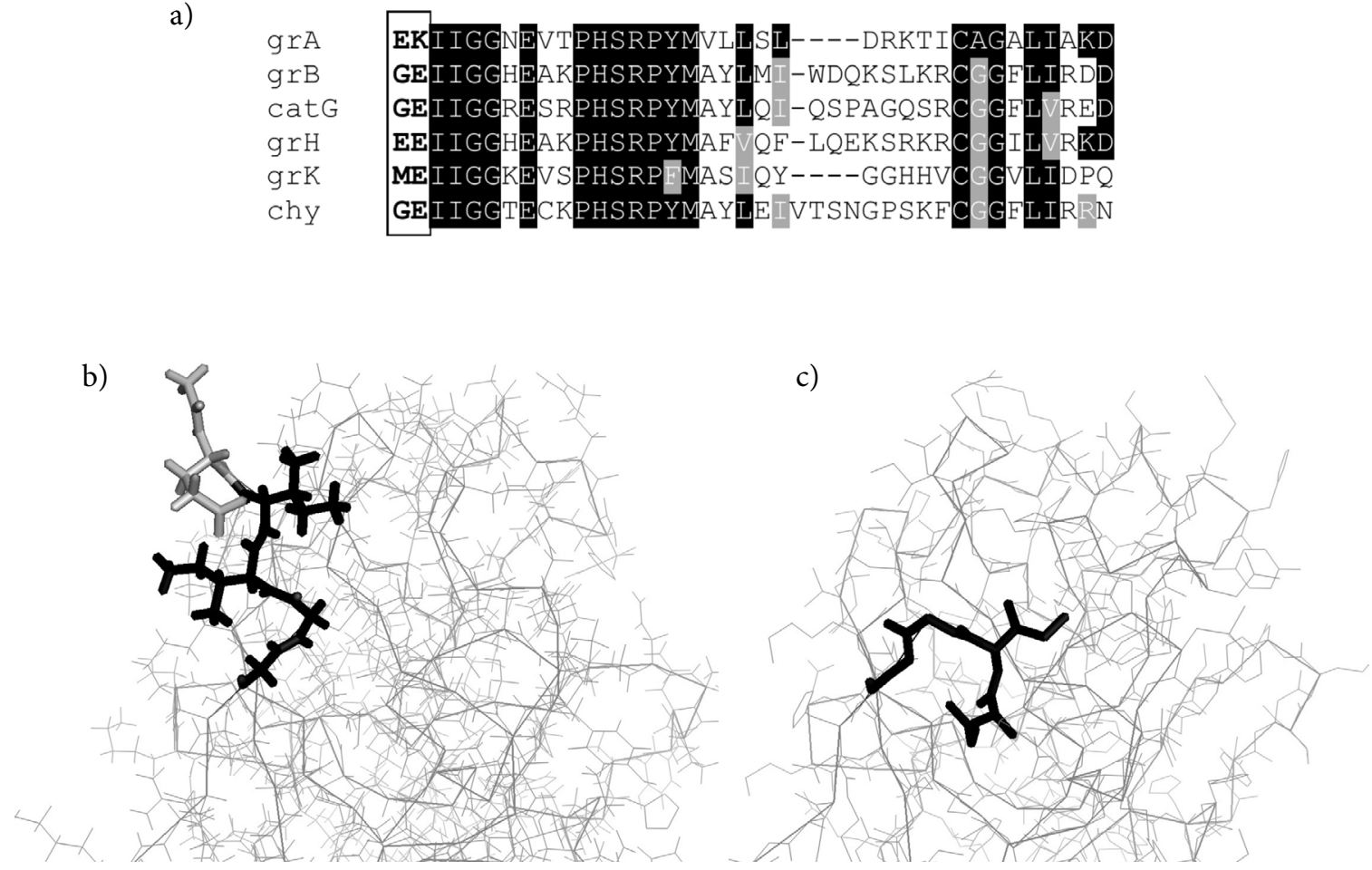

Figure 6. Prodipeptides of granzymes A and B, together with highly similar N-terminal parts are preventing the activity of the granzymes. Following the removal of prodipeptide, the truncated enzyme undergoes structural rearrangement yielding an active enzyme. (a) Sequence alignment of N-terminal of human granzymes A, B, H, and K (grA, grB, grH, grK, respectively), cathepsin G (catG), and chymase (chy). Prodipeptides are marked by the box. Identical amino acids have a black background, and similar amino acids have a grey background. The alignment was performed using Clustal Omega, and shading was done using the BoxShade online service. (b, c) A comparison of modeled progranzyme B (b) with the structure of mature granzyme B (c) (PDB entry 1IAU). N-terminal residues of both molecules are marked with thicker lines. The prodipeptide of granzyme B, pointed out and accessible to cathepsin $\mathrm{C}$, is marked by light gray. The $\mathrm{N}$-terminal part of the reposition of the mature granzyme is perceived. 
des competitively inhibited cathepsin $C$ with the $K_{i}$ values in the same range. ${ }^{21}$ However, it seems that the P1' position of the substrate is also important for hydrolysis by cathepsin C. Comparing the interaction of several dipeptide-amides ${ }^{21}$ and dipeptidyl-fluorogenic or protein substrates $^{21}$ with cathepsin $C$, seems that a bulky group like $\beta$-naphthylamide in Gly-Phe- $\beta$-naphthylamide or AMC in Gly-Glu-AMC facilitate hydrolysis, ${ }^{21,22}$ whereas an amide group or a free $\mathrm{N}$-terminus such as in Gly-Phe- $\mathrm{NH}_{2},{ }^{21} \mathrm{Gly}$ -Glu and Gly-Glu- $\mathrm{NH}_{2}$ in some cases facilitate inhibition of the enzyme.

To gain insight in the inhibitory nature of prodipeptides we performed molecular docking predictions. The calculated prediction for the dipeptide amide Gly-Tyr$-\mathrm{NH}_{2}$, a substrate which is polymerized by cathepsin $\mathrm{C}$, on S2 and S1 positions corresponds to the experimentally positioned inhibitor Ser-Tyr-CN, bound into cathepsin C cleft, ${ }^{22}$ as well to the predicted position of the tetrapeptide Glu-Arg-Ile-Ile. ${ }^{18}$ However, the inhibitory dipeptides bind differently. In contrast to Gly-Tyr- $\mathrm{NH}_{2}$, docking predictions for dipeptides Glu-Lys and Gly-Glu show non-productive binding to the active site of cathepsin $\mathrm{C}$. The inhibitory dipeptides bind to the enzyme on positions in the area of S1 and S1', and are stabilized by surrounding amino acids of cathepsin C. Thus, by binding to the active site of the enzyme, dipeptides interfere the interaction of cathepsin $\mathrm{C}$ with substrates. Knowing that the proregion dipeptides of granzyme A and B can not polymerize, but are weak inhibitors of cathepsin $\mathrm{C}$, raises the question regarding the physiological importance of the prodipeptides. The model of progranzyme $B$ structure revealed very different $\mathrm{N}$-termini positions of progranzyme $\mathrm{B}$ and granzyme B. ${ }^{38}$ Only the exposed $\mathrm{N}$-terminus of progranzyme $\mathrm{B}$ is accessible to cathepsin C. As observed in granzyme $\mathrm{C}^{39}$ and $\mathrm{K},{ }^{5}$ the truncation of the polypeptide chain for two amino acids with cathepsin $\mathrm{C}$ results in a rapid allosteric reorientation, remodeling of the activation domains, and activation. We suggest that the released propeptide, together with the newly formed $\mathrm{N}$-terminus Ile-Ile, ${ }^{40}$ may at least partially block the activities of cathepsin $\mathrm{C}$ within the granules, especially at high local concentrations. The importance of native sequence of granzymes was revealed by mutation studies. Namely, introduction of any mutation in the region of the six $\mathrm{N}$-terminal amino acid residues resulted in lower stability or in an incorrect activation process. ${ }^{41,42}$ Expressing granzyme B without the $\mathrm{N}$-terminal dipeptide yielded a low level of active enzyme which was unstable. ${ }^{41}$ Moreover, a Glu residue at the $\mathrm{P} 1$ position of granzyme $\mathrm{K}$ was shown to be critical, as any mutations resulted in expression of inactive enzyme. ${ }^{42}$

Little is known about the regulation of cathepsin C activity. Basically, the enzyme activity is regulated by the endogenous protein inhibitors to prevent a granzyme maturation to the active form. Based on the size of granules, ${ }^{43}$ we can estimate that $\mathrm{mM}$ concentration is reached by 2000 dipeptide molecules, when granules have diameter of 200 $\mathrm{nm}$. The concentration of the released propeptide dipeptides may be too low to inhibit cathepsin C. However, granzymes and other serine proteases listed in the Figure 6A have similar structure of propeptides. Therefore, we suggest that all the released dipeptides from granule serine proteases may have effect on cathepsin C.

The development of cathepsin $\mathrm{C}$ inhibitors might serve as effective therapeutics for the treatment of diseases, such as inflammatory diseases including rheumatoid arthritis, cystic fibrosis and pulmonary disease. The current therapeutic strategy is based on inhibitors derived from the dipeptidyl substrates, which contain an electrophilic "warhead", such as diazoketones, vinyl sulfones, nitriles, and cyanamides, forming reversible or irreversible covalent bonds with the enzyme active site Cys $234 .{ }^{44}$ Their effective inhibition is at concentration of $\mu \mathrm{M}$ range. However, only few data show biological effects in vivo. Currently, a variety of cathepsin $\mathrm{C}$ inhibitors are used in preclinical and clinical studies. ${ }^{12}$

\section{Conclusion}

In the present study we suggest that the proregion dipeptides of granzymes A and B represent a feedback loop to control the transferase and peptidase activities of cathepsin C. This insight sheds light on the regulation of cathepsin $\mathrm{C}$ activity in biological processes and broadens the knowledge about the role of dipeptides in the mechanisms of cytotoxicity of NK cells. Moreover, the studied dipeptides show immunomodulatory effect. In conclusion, an increase in cytotoxicity is not the result of potentially toxic polymers produced by cathepsin $\mathrm{C}$, but is rather due to modulation of NK cell activity as shown for Glu-Tyr. ${ }^{45}$ This study might be important for possible design of immunosuppressive dipeptide-like drugs.

\section{Acknowledgments}

The authors wish to thank Dr. Vito Turk for critical comments on the manuscript, Dr. Boris Turk for discussion, advice and continuous support. I am grateful to Dr. Dušan Turk for his critical discussion about structural aspects, and to Andreja Sekirnik for expression of recombinant cathepsin C. This study was supported by grants from the Slovenian Research Agency research program P1-0140 lead by Dr. Boris Turk.

\section{References}

1. E. Vivier, E. Tomasello, M. Baratin, T. Walzer and S. Ugolini, Nat. Immunol. 2008, 9, 503-10. DOI:10.1038/ni1582

2. L. Martinet and M. J. Smyth, Nat. Rev. Immunol. 2015, 15, 243-54. DOI:10.1038/ni1582 
3. I. Voskoboinik, J. C. Whisstock and J. A. Trapani, Nat. Rev. Immunol. 2015, 15, 388-400. DOI:10.1038/nri3839

4. C. T. Pham and T. J. Ley, Proc. Natl. Acad. Sci. U. S. A. 1999, 96, 8627-32.

5. C. Hink-Schauer, E. Estebanez-Perpina, E. Wilharm, P. Fuentes-Prior, W. Klinkert, W. Bode and D. E. Jenne, J. Biol. Chem. 2002, 277, 50923-33. DOI:10.1074/jbc.M207962200

6. J. Rotonda, M. Garcia-Calvo, H. G. Bull, W. M. Geissler, B. M. McKeever, C. A. Willoughby, N. A. Thornberry and J. W. Becker, Chem. Biol. 2001, 8, 357-68. DOI:10.1016/S1074-5521(01)00018-7

7. J. W. Heusel, R. L. Wesselschmidt, S. Shresta, J. H. Russell and T. J. Ley, Cell. 1994, 76, 977-87.

\section{DOI:10.1016/0092-8674(94)90376-X}

8. V. Turk, V. Stoka, O. Vasiljeva, M. Renko, T. Sun, B. Turk and D. Turk, Biochim. Biophys. Acta. 2012, 1824, 68-88.

DOI:10.1016/j.bbapap.2011.10.002

9. V. Turk, D. Turk, I. Dolenc and V. Stoka, Acta Chim. Slov. 2019, 66, 5-17. DOI:10.17344/acsi.2018.4639

10. N. V. Rao, G. V. Rao and J. R. Hoidal, J. Biol. Chem. 1997, 272, 10260-5. DOI:10.1074/jbc.272.15.10260

11. E. R. Unanue, V. Turk and J. Neefjes, Annu. Rev. Immunol. 2016, 34, 265-97. DOI:10.1146/annurev-immunol-041015-055420

12. B. Korkmaz, G. H. Caughey, I. Chapple, F. Gauthier, J. Hirschfeld, D. E. Jenne, R. Kettritz, G. Lalmanach, A. S. Lamort, C. Lauritzen, M. Legowska, A. Lesner, S. Marchand-Adam, S. J. McKaig, C. Moss, J. Pedersen, H. Roberts, A. Schreiber, S. Seren and N. S. Thakker, Pharmacol. Ther. 2018, 190, 202-236. DOI:10.1016/j.pharmthera.2018.05.011

13. B. Turk, D. Turk, I. Dolenc and V. Turk, in: G. Salvesen and N. D. Rawlings (Eds.): Handbook of Proteolytic Enzymes, Academic Press, Amsterdam, Netherlands, 2013, pp. 1968-1974. DOI:10.1016/B978-0-12-382219-2.00447-6

14. V. Stoka, V. Turk and B. Turk, Ageing Res Rev. 2016, 32, 22-37. DOI:10.1016/j.arr.2016.04.010

15. C. Hewitt, D. McCormick, G. Linden, D. Turk, I. Stern, I. Wallace, L. Southern, L. Zhang, R. Howard, P. Bullon, M. Wong, R. Widmer, K. A. Gaffar, L. Awawdeh, J. Briggs, R. Yaghmai, E. W. Jabs, P. Hoeger, O. Bleck, S. G. Rudiger, G. Petersilka, M. Battino, P. Brett, F. Hattab, M. Al-Hamed, P. Sloan, C. Toomes, M. Dixon, J. James, A. P. Read and N. Thakker, Hum. Mutat. 2004, 23, 222-8. DOI:10.1002/humu.10314

16. D. S. John, J. Aschenbach, B. Kruger, M. Sendler, F. U. Weiss, J. Mayerle, M. M. Lerch and A. A. Aghdassi, J. Biol. Chem. 2019, 294, 697-707. DOI:10.1074/jbc.RA118.004376

17. A. Paris, B. Strukelj, J. Pungercar, M. Renko, I. Dolenc and V. Turk, FEBS Lett. 1995, 369, 326-30. DOI:10.1016/0014-5793(95)00777-7

18. D. Turk, V. Janjic, I. Stern, M. Podobnik, D. Lamba, S. W. Dahl, C. Lauritzen, J. Pedersen, V. Turk and B. Turk, EMBO J. 2001, 20, 6570-82. DOI:10.1093/emboj/20.23.6570

19. I. Dolenc, B. Turk, G. Pungercic, A. Ritonja and V. Turk, J. Biol. Chem. 1995, 270, 21626-31.

DOI:10.1074/jbc.270.37.21626

20. I. Dolenc, B. Turk, J. Kos and V. Turk, FEBS Lett. 1996, 392, 277-80. DOI:10.1016/0014-5793(96)00828-9
21. J. K. McDonald, B. B. Zeitman, T. J. Reilly and S. Ellis, J. Biol. Chem. 1969, 244, 2693-709.

22. J. K. Rubach, G. Cui, J. L. Schneck, A. N. Taylor, B. Zhao, A. Smallwood, N. Nevins, D. Wisnoski, S. H. Thrall and T. D. Meek, Biochemistry. 2012, 51, 7551-68. DOI:10.1021/bi300719b

23. R. M. Metrione, A. G. Neves and J. S. Fruton, Biochemistry. 1966, 5, 1597-604. DOI:10.1021/bi00869a021

24. D. L. Thiele and P. E. Lipsky, Proc. Natl. Acad. Sci. U. S. A. 1990, 87, 83-7.

25. G. Droga-Mazovec, L. Bojic, A. Petelin, S. Ivanova, R. Romih, U. Repnik, G. S. Salvesen, V. Stoka, V. Turk and B. Turk, J. Biol. Chem. 2008, 283, 19140-50. DOI:10.1074/jbc.M802513200

26. U. Repnik, M. Hafner Cesen and B. Turk, Mitochondrion. 2014, 19 Pt A, 49-57. DOI:10.1016/j.mito.2014.06.006

27. J. Bozic, V. Stoka and I. Dolenc, PLoS One. 2018, 13, e0200757. DOI:10.1371/journal.pone.0200757

28. S. W. Dahl, T. Halkier, C. Lauritzen, I. Dolenc, J. Pedersen, V. Turk and B. Turk, Biochemistry. 2001, 40, 1671-1678. DOI:10.1021/bi001693z

29. M. Shibue, C. T. Mant and R. S. Hodges, J. Chromatogr. A. 2005, 1080, 58-67. DOI:10.1016/j.chroma.2005.02.047

30. E. F. Pettersen, T. D. Goddard, C. C. Huang, G. S. Couch, D. M. Greenblatt, E. C. Meng and T. E. Ferrin, J. Comput. Chem. 2004, 25, 1605-12. DOI:10.1002/jcc.20084

31. O. Trott and A. J. Olson, J. Comput. Chem. 2010, 31, 455-61. DOI: $10.1002 /$ jcc. 21334

32. Y. Zhang, BMC Bioinformatics. 2008, 9, 40. DOI:10.1186/1471-2105-9-40

33. K. K. Nilsson and J. S. Fruton, Biochemistry. 1964, 3, 1220-4. DOI:10.1021/bi00897a006

34. S. D. Abbott, L. Gagnon, M. Lagraoui, S. Kadhim, G. Attardo, B. Zacharie and C. L. Penney, J. Med. Chem. 1998, 41, 19091926. DOI:10.1021/jm970734v

35. B. K. Tubic, S. S. Vladimirov, B. D. Markovic and T. J. Sabo, Acta Chim. Slov. 2018, 65, 59-64. DOI:10.17344/acsi.2017.3477

36. A. B. Nongonierma and R. J. FitzGerald, Peptides. 2013, 39, 157-63. DOI:10.1016/j.peptides.2012.11.016

37. Y. Zhang, R. Chen, X. Chen, Z. Zeng, H. Ma and S. Chen, J. Agric. Food Chem. 2016, 64, 831-9. DOI:10.1021/acs.jafc.5b05429

38. S. M. Waugh, J. L. Harris, R. Fletterick and C. S. Craik, Nat. Struct. Biol. 2000, 7, 762-5. DOI:10.1038/78992

39. D. Kaiserman, A. M. Buckle, P. Van Damme, J. A. Irving, R. H. Law, A. Y. Matthews, T. Bashtannyk-Puhalovich, C. Langendorf, P. Thompson, J. Vandekerckhove, K. Gevaert, J. C. Whisstock and P. I. Bird, Proc. Natl. Acad. Sci. U. S. A. 2009, 106, 5587-92. DOI:10.1073/pnas.0811968106

40. T. V. Tran, K. A. Ellis, C. M. Kam, D. Hudig and J. C. Powers, Arch. Biochem. Biophys. 2002, 403, 160-70.

DOI:10.1016/S0003-9861(02)00217-5

41. M. J. Smyth, M. J. McGuire and K. Y. Thia, J. Immunol. 1995, 154, 6299-305.

42. E. Wilharm, M. A. Parry, R. Friebel, H. Tschesche, G. Matschiner, C. P. Sommerhoff and D. E. Jenne, J. Biol. Chem. 1999, 274, 27331-7. DOI:10.1074/jbc.274.38.27331 
43. J. P. Goodridge, B. Jacobs, M. L. Saetersmoen, D. Clement, Q. Hammer, T. Clancy, E. Skarpen, A. Brech, J. Landskron and C. Grimm, Nat. commun. 2019, 10, 514.

DOI:10.1038/s41467-019-08384-X
44. D. I. Laine and J. Busch-Petersen, Expert Opin. Ther. Pat. 2010, 20, 497-506. DOI:10.1517/13543771003657172

45. D. L. Smith, J. Cai, S. Zhu, W. Wei, J. Fukumoto, S. Sharma, R. Masood and P. S. Gill, Int. J. Cancer. 2003, 106, 528-33. DOI:10.1002/ijc.11253

\section{Povzetek}

Katepsin C (dipeptidil peptidaza I) aktivira grancima A in B s proteolitično odstranitvijo N-terminalnih dipeptidov. Možna fiziološka vloga odcepljenih dipeptidov Glu-Lys in Gly-Glu ni znana. V naši študiji smo pokazali, da je dodatek omenjenih dipeptidov k celicam NK-92 povzročil njihovo povečano citotoksičnost in s tem hitrejšo smrt tarčnih celic K562. Katepsin C lahko tvori citotoksične polimere iz različnih dipeptidov, vendar dipeptidov Glu-Lys in Gly-Glu encim ni sposoben polimerizirati. Pri tem smo ugotovili, da sta dipeptida šibka inhibitorja transferazne aktivnosti katepsina $C$ (IC50 $<20 \mathrm{mM}$ ) in kompetitivna inhibitorja njegove proteolitične aktivnosti, z vrednostmi $\mathrm{K}_{\mathrm{i}} \mathrm{v}$ milimolarnem območju. Rezultati odkrivajo potencialno vlogo teh dveh dipeptidov, ki lahko s povratno regulacijo vplivajo na transferazno in proteolitično aktivnost katepsina $\mathrm{C}$ v različnih bioloških procesih. 